International Journal of Social Sciences and Humanities
Available online at http://sciencescholar.us/journal/index.php/ijssh
Vol. 2 No. 2, August 2018, pages: 124 140
e-ISSN: 2550-7001, p-ISSN: 2550-701X
https://doi.org/10.29332/ijssh.v2n2.152

\title{
Legal Pluralism Politics towards Recognition of Social Unity in Customary Law and Local Regulation
}

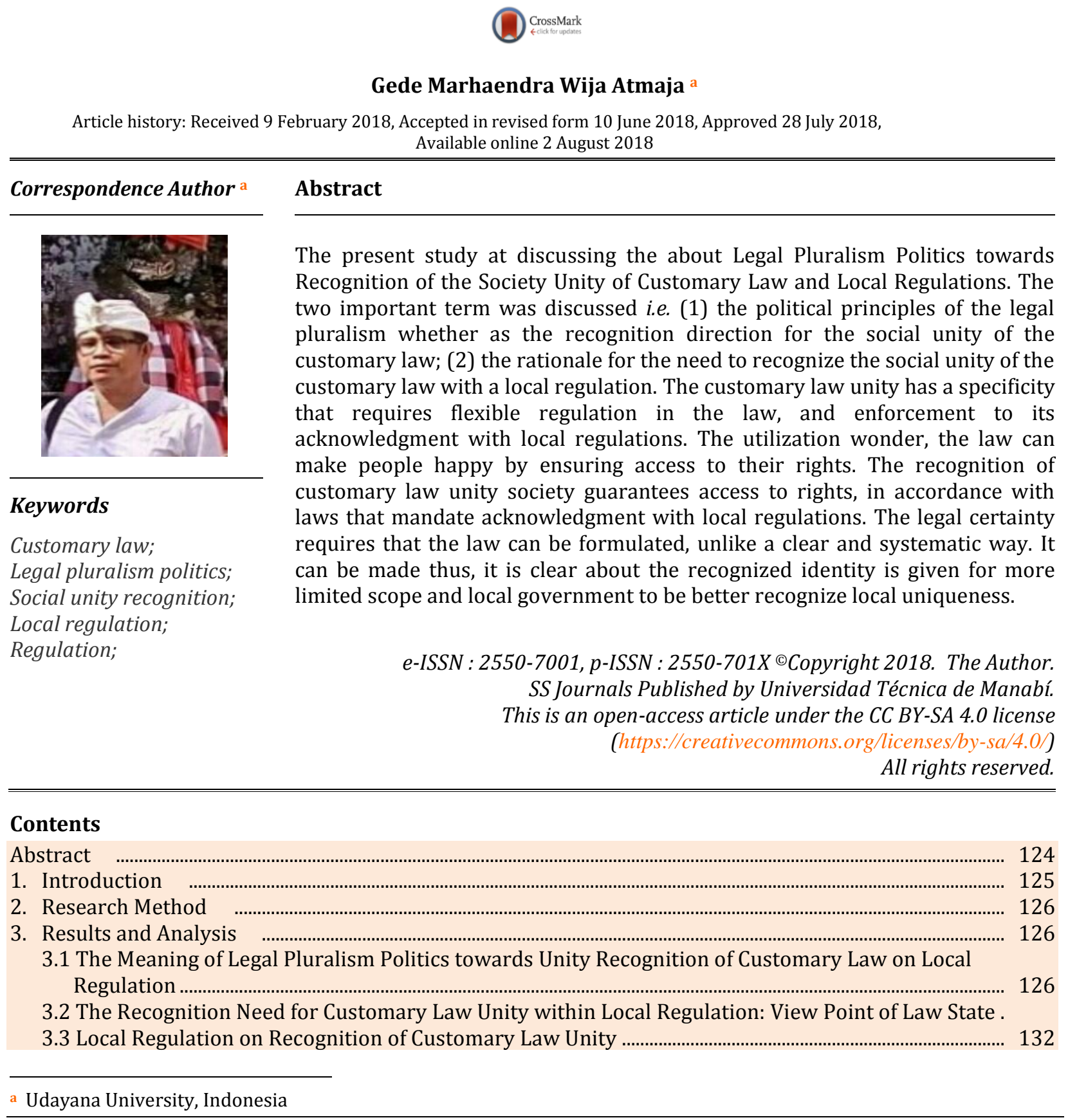




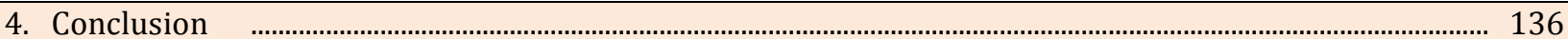

Conflict of interest statement and funding sources ............................................................................................ 137

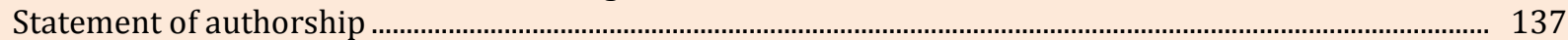

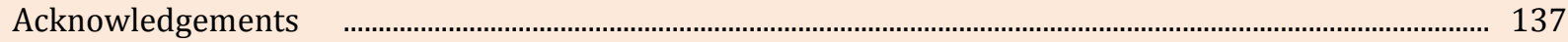

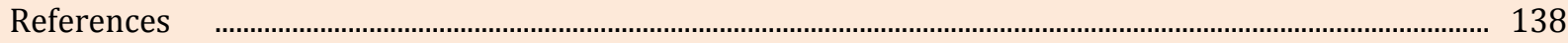

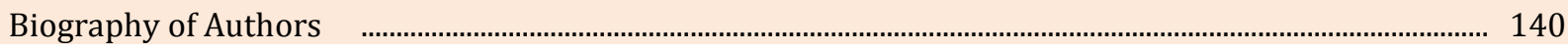

\section{Introduction}

The article 18B section (2) Constitution of the Republic of Indonesia 1945 (hereinafter referred to UUD NRI 1945) established "the State recognizes and respects towards the customary law societies and their traditional rights throughout exist and in accordance with the society development and the principles of the Unitary State of the Republic of Indonesia, stipulated in the regulation." The law text ${ }^{1}$ itself consists of the norm that was an unclearness in the phrase "regulated by the law", it occurred conflict interpretations. The first interpretation, "regulated by law" means its existence has been recognized under the law and establishes that confession with the local regulations. The second interpretation, "regulated by the law" defines the law recognizing its existence. The first interpretation was adopted by lawmakers, ${ }^{2}$ especially those set in the laws number on natural resources and the regulations on the local government. The law on the natural resources is: Law No. 41 / 1999 regarding Forestry, as amended by Law No. 19 / 2004 (hereinafter referred to UU No. 41/1999); Law No. 7 / 2004 on Water Resources (hereinafter referred to UU No. 7/2004); Law No. 18 / 2004 on Plantation (hereinafter referred to UU No. 18/2004).

The laws on the local administration is Law No. 21 in 2001 regarding Special Autonomy for Papua Province, as amended by Law No. 35 in 2008 (hereinafter referred to Law No. 21/2001); Law No. 32 in 2004 regarding Local Government, as amended by Law No. 12 in 2008 (hereinafter referred to Law No. 32/2004); Law No. 11 in 2006 about Aceh Government (hereinafter referred to Law No. 11/2006). The second interpretation is embraced by the applicant in the judicial review of Law No. 7/2004 on the 1945 UUD NRI 1945, which holds that the recognition of the customary rights over the water resources insofar as the fact remains and has been confirmed by the local law, contrary to Article 18B section (2) UUD NRI 1945 that determines "regulated in the law".3

The Constitutional Justice, A. Mukthie Fadjar, in the dissenting opinion, as well as held the same opinion that the unity of the society and customary law is unconstitutional. It's a contrary opinion that the Constitutional Court stated that the petition for judicial review to declare Article 6 section (3) Law No. $7 / 2004$ as contradictory to UUD NRI 1945 is not sufficient. ${ }^{4}$ It defines that Article 6 section (3) of Law No. 7/2004 is not contradictory to Article 18 B Section (2) UUD NRI 1945. In essence, the recognition of the regional regulations as stipulated in the law is constitutional. Saptomo (2010), the necessary clarity is the underlying notion of the need for recognition by local legislation. It deals with the principle of setting a necessity. The necessity principle (het noodzakelijkeheids beginsel) is the principles of a good legislation formulation (beginselen van behoorlijke regelgeving) which is formal in the division included I.C. Van der Vlies, followed by A. Hamid S. Attamimi. Leyh (2011), it is for ensuring that the objectives achievement is conducted by making a

\footnotetext{
${ }^{1}$ Law as text is a law that encountered in text or laws/laws formally deliberately rationalized. Satjipto Rahardjo, Law and Behavior: Good Life is Good Law Foundation, (Jakarta: Kompas Book Publishers, 2009), p. 11. UUD NRI 1945, in accordance with Article 7 section (1) Law No. 12 in 2011 regarding the Establishment of Laws and Regulations is one of legislation type, which occupies the highest position in the legislation hierarchy.

2 As well as, it is argued by the Constitutional Court stated that "regulated by the law" as its existence has been recognized under the law applicable as a reflection of the development of values considered ideal in nowadays society, both public and sectorial laws, unlike agrarian, forestry, fishery, and others as well as in the local regulations. Decree No. 31 / PUU-V / 2007, assessment of Law No. 31 in 2007 on the Establishment of Tual City in Maluku Province on UUD NRI 1945, p. 165-166. Decree No. 6 / PUU-VI / 2008, Law No. 51/1999 on the Buol Regency Formation, Morowali Regency and Banggai Regency Island on UUD NRI 1945, p. 134-135.

3 The reasons for the petition and petitum unlike included in the Case Decision No. 058-059-060-063 / PUU-II / 2004, Case No. 008 / PUU-III / 2005 , p. 51, 57.

${ }^{4}$ Decision on Case No. 058-059-060-063 / PUU-II / 2004, Case No. 008 / PUU-III / 2005, p. 508, 512.
}

Atmaja, G. M. W. (2018). Legal pluralism politics towards recognition of social unity in customary law and local regulation. International Journal of Social Sciences and Humanities, 2(2), 124-140. https://doi.org/10.29332/ijssh.v2n2.152 
rule and intends to avoid the possibility of issuing a regulation that is not actually needed. This principle grows due to there is always an alternative to solve a government issue other than establishing a legislation. ${ }^{5}$

The necessity principle, in Law No. 12 / 2011 on the Legislation Establishment of (hereinafter referred to Law No. 12/2011), is referred to as the basis of usability, the Legislation is made due to it is absolutely necessary and beneficial in regulating the society life, nation, and state (Article 5 letter $e$ and its Explanation). ${ }^{6}$ The clarity about an idea that underlying the recognition needed for the unity of indigenous and tribal peoples with local regulation, derives its foundation on the establishment principles is good legislation, precisely on the necessity principle of unity. It is as well as important to understand the other problematic encompassing Article 18B section (2) UUD NRI 1945. Among of them are problematic antinomies, related to Article 1 section (1) UUD NRI 1945. "Indonesia is a Unitary State ...", and Article 27 section 1) UUD NRI 1945. "All citizens are equal in the position of law and government ...". Article 18B section (2) UUD NRI 1945 is the basis for legal pluralism, whereas Article 1 section (1) UUD NRI 1945 on Unitary State and Article 27 section (1) UUD NRI 1945 concerning the prohibition of discrimination is a basis for law unification. ${ }^{7}$

Unclarity legal norms in Article 18B section (2) UUD NRI 1945 have a potential occurred sociologicalempirical implications in the form of constitutional impairment for customary law society unity (Rahman, 2011). Due to uncertainty itself has a potential is used as a basis for justifying the rights abandonment consisted of, which results in non-realization for those rights, even violations. ${ }^{8}$ This is evident in every dispute one of the party is a unity of legal law always defeated by unity of indigenous and tribal peoples (Li, 1999). An acknowledgment with local regulations can be constructed and vagueness of legal norms by providing reinforcement to the recognition urgency with local regulations.

\section{Research Method}

The research model in the present study is used a qualitative. The theory is adopted based on the regulation belonging in the Indonesian government. The technique of collecting the data is applied library research. The explanation for each phenomenon is paraphrase descriptively.

\section{Results and Analysis}

\subsection{The Meaning of Legal Pluralism Politics towards Unity Recognition of Customary Law on Local Regulation}

Historically, both discussing on UUD NRI 1945 in BPUPKI and PPKI as well as amendment UUD NRI 1945 MPR, indicate that there is a desire to recognize and respect the volunteering or customary law society units. Bedner (2010), there is a will by MPR to oblige states to recognize the diversity of customary law societies.

\footnotetext{
${ }^{5}$ I.C. Van der Vlies, Handbook of Legislation Design, translated by Linus Doludjawa, the original title: Handbook Wetgeving, (Published by the Directorate General of Legislation and Regulation of the Department of Law and Human Rights of the Republic of Indonesia, Jakarta, 2005), p. 271-274, 284. A. Hamid S. Attamimi, "The Role of Presidential Decree of the Republic of Indonesia in the Implementation of State Administration", Doctoral Dissertation, (Postgraduate Program of University of Indonesia, Jakarta, 1990), p. 338, 345. Yuliandri, "Principles for the Good Legislation Establishment in the Framework of the Making of Continuity Law", Doctoral Dissertation, (Surabaya: Postgraduate Program of Airlangga University, 2007), p. 142-145

${ }^{6}$ The necessity principle is also recognized in the practice of public policy making upon member states of (Organization for Economic Cooperation and Development/OECD), which is covered by the Regulatory Impact Analysis (RIA). RIA is a method that aims to assess systematically the negative and positive effects of proposed or ongoing rules. One principle is minimum effective regulation, that ensure a conducive regulatory climate, rule is only a minimum requirement to achieve the desired objectives. It defines there is indeed a real problem and needs to be solved, and there is no non-regulatory alternative available to achieve the desired goals. One of the steps that RIA program recommends is an alternative actions selection that can be done to achieve the goal. The alternative forms are (1) self regulation; (2) quasi regulaton; and (3) explicit regulation. Ida Nurseppy, Paryadi, and David Ray, "Handbook of Indonesian Rules Review" presented in the Seminar on November $28^{\text {th }}$, 2002, Nusa Dua Bali Province, in Cooperation with Balitbang Indag Depperindag, Disperindag Bali Province, PEG, USAID, p. $4-5,10-11$.

7 Tristam P. Moeliono, "Should We Re-Question the National Law Unification Idea", in Elly Erawati, Bayu Seto Hardjowahono, and Ida Susanti, eds., Some Thoughts on the Development of Indonesia Nationality Legal System: Liber Amicorum for Prof. Dr. CFG. Sunaryati Hartono, S.H., (Bandung: Citra Aditya Bakti, 2011), p. 133.

8 Kompas, Thursday, August $10^{\text {th }}, 2008$, "Acknowledge the Existence and Customary Law Rights, the government agreed to prepare RUU for protecting the Customary Law Rights"; http://rafflesia.wwf.or.id 7/1/2009; Martua Sirait, et.al., eds., 1999, "How Customary Law Rights in Managing the Natural Resources Organized", Southeast Asia Policy Research Working Paper, No. 24, p. 16-23; and Martua Sirait, et.al., eds., 1999, "How Indigenous People Rights in Natural Resource Management Regulates in Indonesia", Southeast Asia Policy Research Working Paper, No. 24, p. 15-21; http://www.worldagroforestry.org 8/1/2009.
} 
The recognition can be done by giving one-to-one recognition to the unity of customary law society, which is given by the local government through local regulations. Therefore, the meaning of the state in Article 18B section (2) UUD NRI 1945 is more as a function of state government functions than the state in the sense of structure which refers to a particular institution. The Regional Regulation as a legislation type to make concrete adjunctions is derived from the meaning of "regulated in law", i.e. the material concerned arrangement does not require separate law specifically regulating it. The law as referred to in Article 18B section (2) UUD NRI 1945 provide material on the direction of recognition and respect policy for customary law unity, unlike clarifying the recognition requirements as enjoined in UUD NRI 1945.

The unity of customary law society is a fact of law plague, unlike conceptually described, the historical approach in Article UUD NRI 1945 which was later changed into Article 18B section (2) UUD NRI 1945, the existence of 19 (Nineteen) customary law environments and their exploration. In the customary law environment and its exploration, there are customary law society units, unlike the customary law bearers. More concretely, for example, the existence of desa pakraman as a customary law society unit in Bali, which cultivate from Balinese-Lombok customary law, reinforces the pluralism constituency. Therefore, it is more appropriate to recognize one by one of customary law society units by the local district /city government. One-by-one recognition may be conducted either individually on an indigenous legal society (e.g. in Bali, the recognition is desa pakraman) or the concurrent recognition by some customary law society units (e.g. for Bali is the recognition by some desa pakraman). Thus, the need for unity recognition of customary law society is due to the indigenous plurality and tribal peoples' unity, which requires the recognition of one by one existing legal society units. This is not exactly done by the central government, either through laws or government regulations, or presidential regulations. However, it is more appropriate to be done by the local government as stated in the local regulations. Due to they know more about the pluralism in their area and the local people have more access to participate in the local regulations formation that recognizes the unity of indigenous and tribal peoples (Manan, 1990).

\subsection{The Recognition Need for Customary Law Unity within Local Regulation: View Point of Law State}

The state of law based on Brian Z. Tamanaha approach as stated in Chapter II is the concept of law as a basis for the state organizers actions. The law is intended not only the law that consists of legal certainty made democratically (a formal version of the state of the law), however, as well as ensure justice and benefit for the people in improving their welfare (a substantive version of the state of the law). Vujčić (2006), the alternative approach of the state of law affirms the conception of a state of law that guarantees justice, benefit, and legal certainty. This approach is used to assess the need for recognition of the unity of indigenous and tribal peoples with local regulations.

a) A plurality of Customary Law Units in the State of Law Context

The diversity of religions, ethnicities, and geographies in Indonesia, an inevitable plurality, requires a fairly neutral political norm to keep the country's integrity and peace with ease. ${ }^{9}$ It turns is meant by "fairly neutral political norm" is understanding of law state, as stated in the following quotation:

For religious and ethnic minorities, therefore the state of law has implications desired change as well as conservative defense. On the one hand, the state of law promise greater political influence than they can derive from the basis of power. On the other hand, the state of law gives hope to every group that aggressive intentions in all classes, as well as from the government itself, can be prevented. The ideological dimension of developing state of law included the idea that religious and ethnic interests are sealed by the principles of political neutrality in facing a prominent cultural issue. ${ }^{10}$

Lask, et.al. (1950), the quote indicates the state of law can provide normative assurance against pluralism. This can be understood in relation to the alternative approach of the state of law by Brian Z. Tamanaha, the

9 Daniel S. Lev, Law and Politics in Indonesia: Sustainability and Change (Jakarta: LP3ES, 1990), p. 188.

${ }^{10}$ Daniel S. Lev, Law and Politics in Indonesia: Sustainability and Change (Jakarta: LP3ES, 1990), p. 387-388.

Atmaja, G. M. W. (2018). Legal pluralism politics towards recognition of social unity in customary law and local regulation. International Journal of Social Sciences and Humanities, 2(2), 124-140. https://doi.org/10.29332/ijssh.v2n2.152 
law is a government instrument including a certainty is made democratically and ensures personal rights, justice and dignity, and social welfare, it unlike has been described in a theoretical framework. In essence, the law constitutes as an instrument of government guarantees justice, benefit, and legal certainty that is democratically made. It defines open access to legal participation.

Thus, the pluralistic societies have guaranteed access to engage in lawmaking. The legal participation, as described in the Theoretical Framework, is one of the elements of legal pluralism politics or the state pluralism law. In short, the legal pluralism deals with the rule of law. The state of law normatively guarantees legal pluralism. It was as well as described in section two, the alternative approach of the state of the law was developed by Adriaan Bedner into 3 (three) categories. The first category is procedural elements, includes (1) the law as a government instrument; (2) the state action is under the law; (3) formal legality; and (4) democracy. The second category is substantive elements, includes (1) moral and justice principles; (2) individual human rights; (3) social rights; and (4) group and cultural rights. The third category is the institutional element i.e. the oversight mechanism and implementing agency. ${ }^{11}$

Referring to the second category is a substantive element, particularly the element of "group and culture rights", theoretically, the unity of indigenous and tribal peoples as a group or collectivity has a place in the state of law theory, as stated by Adriaan Bedner. Unlike a group, indigenous and tribal peoples have collective and cultural rights, which must be protected (Nahak, 2017; Suarta, 2017).

b) The State of Law Regulation in UUD NRI 1945, Historical Approach

Article 1 section (3) UUD NRI 1945, "The State of Indonesia is a state of law." The provision is not included inside of UUD NRI 1945 (before amendment). The statements of the state of law are provided in UUD NRI 1945 Elucidation regarding State Government System with the formula "the state of Indonesian based on the law (rechtsstaat)" is formulated under the heading "Indonesia is a state based on the law (rechtsstaat)".

The desire to state explicitly the provisions of the state of the law in articles has emerged during Constituent Assemblies, 1959. J.C.T. Simorangkir, a member of Constituent Assembly of Parkindo, demanded an improvement over lacking explicit formulation within UUD NRI 1945, stated that "the Republic of Indonesia based on the rule of law or Rechtsstaat even though it indeed exists in its Official Explanation." The context that encompasses the current discussion is a dichotomy, Attitude to include decisions that have been taken by Constituent Assembly as an amendment to UUD NRI 1945 and the government's stance that UUD NRI 1945 should be accepted without any change. 12

The desire to state the provisions of the state of law in UUD NRI 1945 was only realized in 2001 - in the Third Amendment, which requires 3 (three) periods of amendments discussion in UUD NRI 1945, i.e. (1) Discussing on the First Amendment Period; (2) Discussing on the Second Amendment Period; and (3) Discussing on the Third Amendment Period. ${ }^{13}$ Discussing the First Amendment, and Discussion at the Second Amendment, develop opinions that are essentially concerned with:

1) The understanding of the state of law refers to rechtsstaat, unlike provided in UUD NRI 1945 General Constitution, is interpreted as a state based on the law. ${ }^{14}$

2) The understanding of the law within the rule of law is to consist of rechtmatig meaning its legal basis is clear, and as well as doelmatig means its use is clear as well. ${ }^{15}$

\footnotetext{
${ }^{11}$ Adriaan Bedner, "An approach ...", Loc. Cit.; Adriaan Bedner \& Jacqueline A.C. Vel, "An Analytical Framework ...", Loc. Cit.

${ }^{12}$ It is cited in Adnan Buyung Nasution, Aspirations of Constitutional Governance in Indonesia: Socio-Legal on Constituencies Studies 19561959, translated by Sylvia Tiwon's of the original title: The Aspiration for Constitutional Government in Indonesia: A Socio-Legal Study of the Indonesian Konstituante 1956-1959, (Pustaka Utama Grafity, Jakarta, 1995), p. 377-378.

${ }^{13}$ The Script Writing Team Process of Amendment Results of UUD NRI 1945, Comprehensive Text of Amendment in UUD NRI 1945, the Background of Process and Discussion Results, 1999-2002, Book II Fundamentals and National Joints (General Secretariat and Registrar of the Constitutional Court, Jakarta, 2008), p. 229-280.

${ }^{14}$ Yusuf Muhammad (F-KB) submitted his opinion on the additional section (3) Article 1 stated that, "Indonesia is a state of law". It is defined that there is an explicit statement of the commitment for the law, it will be a strong foothold for law enforcement efforts in the country response conditions under which law becomes a game of power. Hamdan Zoelva (F-UN) stated that "Thus, let its more assertive due to so far the state law principle is merely in explanation. It is non-explanation in the section. Therefore, it's reinforce in the chapter one concerning the form and sovereignty ". Lukman Hakim Saifuddin (F-PPP) carry out the material of the legal state which was originally consist of the Elucidation in UUD NRI 1945 that will be appointed to the articles. The Script Writing Team ..., Comprehensive Text ...., Ibid., p. 229, 248-249.

${ }^{15}$ Gregori Seto Harianto (F-PDKB) stated that, "... looking at the background of the spiritual atmosphere when the text or principle of the law rule existing in the explanation UUD NRI 1945 actually desirable the law state is translated into the sense of law is one-sided rechtmatig defines the
} 
The discussion on the Third Amendment period began on September 5, 2000. In order to formulate the provisions regarding the rule of law, Formulating Team was formed which consisted of Commission $A$ leaders and factions representatives. The Formulating Team results were presented at the $5^{\text {th }}$ Commission $A$ meeting in 2001 MPR, Annual Session, 8-9 November 2001, led by Jakob Tobing. Commission $A$ results discussion was submitted in Plenary Session in 2001 MPR Annual Session. On these results, the factions gave a final opinion in the 7th Plenary Session in 2001 MPR, Annual Session, November 8, 2001, led by Amien Rais. ${ }^{16}$ Respecting to the provisions the rule of law, the final opinion of the factions is as follows:

1) F-PDI Perjuangan (name of party) is presented by I Dewa Gede Palguna expressed his views: The assertion that "Indonesia is the state of law", in which it as well as means the supremacy of law, democracy, respect for human rights, and restriction of governmental rule by law is very important, therefore, we agree with the formulation in the draft amendments to Article 1 Section (3). ${ }^{17}$

2) F-PG through its spokesman, T.M. Nurlif expressed his opinion, "In the Third Amendment UUD NRI 1945 , we have as well as affirmed that Indonesia is the state of law. Wherein every citizen is equal under the law."18

3) F-PBB by Hamdan Zoelva conveyed, "For our faction, the superior is law and that is why we agree with the formulation of the rule of law."19

The discussion has been done on the importance of ideals awareness for the state of law (rechtsstaat) adopted from UUD NRI 1945 Elucidation, the full formula is "a state based on law, then produced a mutually agreed formula to be submitted in Chapter I Forms and Sovereignty, Article 1 section (3), namely "the State of Indonesia is a state of law". ${ }^{20}$ The amendment can be read as a desire of Indonesian people to further reinforce the identity of their country as a state law. ${ }^{21}$

The search for historical background on Article 1 section (3) UUD NRI 1945, "the State of Indonesia is a state of law" indicates a number of aspects, included:

1) The rule of law is based on an agreement to raise the normative matters explanation into the article. Therefore, the provisions of the state of law consist of UUD NRI 1945 Elucidation, then need to be set forth in the article provisions.

2) The references to the state of law are rechtsstaat as found in UUD NRI 1945 as well as refer to the rule of law.

3) The understanding regarding the rule of law is included democracy/in definition of a democratic constitutional state, and others unlike justice, equality under the law, and human rights.

4) Law comprehension in the concept of a state of the law is a law defines rechtsmatig and doelmatig.

Article 1 section (3) UUD NRI 1945 does not provide clarity on the state of law concept, it embraces. Understanding the meaning of a passage, however, is not enough just studied the text only, but also the underlying context of the text belong even with evolving ideas at the time the text is read. ${ }^{22}$ The discussion on MPR meetings including provisions on the constitutional state, which is finally stated in Article Section 1 (3) UUD NRI 1945, "Indonesia is a state of law" indicates the state law reference is understanding of rechtsstaat and the rule of law.

Desiring is to absorb the good elements of the rule of law concept from wherever it comes, including of rechtsstaat and the rule of law, ${ }^{23}$ is explicitly stated by MPR, "The current official term, as submitted in

legal basis is clear, however also doelmatig means its usefulness is clear as well. "Team Script Writing Team..., Comprehensive Text ...., Ibid. Ibid., p. 244-245.

16 The Constitutional Court ..., Comprehensive Text ...., Ibid. p. 277-278.

${ }^{17}$ The Constitutional Court ..., Comprehensive Text ...., Ibid. p. 278.

18 The Constitutional Court ..., Comprehensive Text ..... Ibid. p. 278-279.

19 The Constitutional Court ..., Comprehensive Text ...., Ibid. p. 279-280. The other factions expressed their final opinion, however did not mention the state of law.

${ }^{20}$ The Constitutional Court ..., Comprehensive Text ...., Ibid. p. 280.

${ }^{21}$ Satjipto Rahardjo, State of Law .... Op. Cit., P. 2.

${ }^{22}$ Cited in Saafroedin Bahar, et.al. eds., Proceedings of Assembly ..., Op. Cit., p. 264.

${ }^{23}$ Rechtsstaat is defined formele rechtsstaat, unlike developed Friedrich Julius Stahl in Germany, consists of 4 (four) elements, i.e. (1) recognition of human rights (grondrechten); (2) separation of power (scheiding van machten); (3) government by the law (wetmatigheid van bestuur); and (4) state administrative court (administrative rechtspraak). Jimly Asshiddiqie, Highlights ..., Ibid. Oemar Seno Adji, Judicial ..., Ibid. A.V. Dicey presents 3 (three) meanings of the rule of law, or commonly referred to as the elements of the rule of law, i.e. (1) absolute supremacy or rampaging of the "regular law" to oppose the influence of "arbitrary power" widespread abuse, prerogative or "discretionary authority" of the

Atmaja, G. M. W. (2018). Legal pluralism politics towards recognition of social unity in customary law and local regulation. International Journal of Social Sciences and Humanities, 2(2), 124-140. https://doi.org/10.29332/ijssh.v2n2.152 
Article 1 section (3), is 'the state of law' that can absorb the substance of rechtsstaat and the rule of law at once." ${ }^{24}$ The next elementary conception of the state of the law is derived by Anglo Saxon UUD NRI 1945 (the rule of law) is established in Article 27 section (1) which affirms that "All citizens are equal under the law and government and must be obliged to uphold a law and government with no exception." 25 Based on the whole description above regarding the law state mentioned, Indonesian State Law can be interpreted as the implementation of the Republic of Indonesia respecting the law of justice guarantees, benefit, and certainty. The view of Indonesian Law State is used to explain the recognition urgency of the unity of indigenous and tribal peoples in local regulations, or the formation urgency of local regulations recognizes the unity of indigenous and tribal peoples (Black, et.al., 1999).

c) The Meaning of the State of Law on the Recognition of Customary Law Unity with Local Regulations

Satjipto Rahardjo based on Gustav Radbruch view stated that the law is required to meet the law basic values, i.e. justice, utility, and legal certainty. ${ }^{26}$ Gustav Radbruch understands the law as a cultural concept, i.e. the concept regarding value. Law as a cultural concept dealing with legal value and law idea, the law that interpreted as the idea to translate the idea of law. Gustav Radbruch explores three (3) legal ideas/ideals of law (the idea of the law), i.e. justice, expediency, and legal certainty.

The three elements of the legal idea are complementary to each other - and in other situations contradict each other. The tension among the three elements of legal value is illustrated by Satjipto Rahardjo, unlike a relationship can be understood, since it consists of different demands and each of them has the potential to contradict. For example, legal certainty as for the basic value of the law immediately shifts the values of justice and usability aside.

Bourchier, et.al. (2014), the main point of legal certainty is the existence of the rule itself. Regarding whether the regulation should be fair and have utility for its people, is beyond the preference of the legal certainty value. ${ }^{27}$ Likewise, Franz Magnis Suseno stated between legal certainty and demands, the law is fit as possible with society justice feeling is tension:

1) The certainty demands on the law are formulated narrowly and strictly, therefore, there is no slight ambiguity. However, the narrower, more stringent, and detailed legal formulation, the more rigid of law and narrower a space of the judge's freedom to observe various subjective factors, thus they can not pay attention to the justice ideas in the society concerned. It is possible that a decision is in accordance with the law norms - fulfilled certainty, however, it is not in accordance with a justice in the public's view.

2) On the one hand, in order for the law to confirm a society justice feeling, the law should be constantly adapted to change in the society. However, this demand is contrary to the legal continuity demands, which demand that it is not quickly changed, which is the demand of legal certainty (the certainty of legal certainty orientation).

3) On the other hand, if the judge is given too much freedom, the door is open to all authority kinds; The settlement of a legal case will depend on the professional quality and moral integrity of the

government; (2) equality before the law or equal subordination to all classes to "ordinary law of the land" assessed by the "ordinary court"; It means that no person is above the law, both officials and ordinary citizens are obliged to abide by the same law, and there is no state administrative court; (3) the constitution is the result of "the ordinary law of the land", that constitutional law is not a source but is a consequence of individual rights formulated and enforced by the judiciary. Albert Venn Dicey, Introduction to the Study of the Law of Constitutions, (London: MacMillan and Co., 1893), p. 191-193. See also Philipus M. Hadjon, Protection ..., Ibid., p. 80; O. Notohamidjojo, Meaning of State of Law, (Salatiga, 1967), p. 28-29.

${ }^{24}$ Provisional People's Consultative Assembly of the Republic of Indonesia (MPR RI), Society Guidance ..., Op. Cit., p. 47. See also Moh. Mahfud MD, Debate ..., Op. Cit., p. 51; Suko Wiyono, "Legal Tests of Regional Regulations in the Implementation of Regional Autonomy Based on Law No. 22 / 1999, Regional Government", Doctoral Dissertation, (Malang: Postgraduate Program of Brawijaya University, 2004), p. 119, stated that the concept on Law State of Pancasila essentially has elements consist of the concept of Rechtsstaat and Rule of Law. The principle difference lies in the foundation of the state philosophy that Law State of Pancasila based on Pancasila philosophy.

${ }^{25}$ Article 27 section (1) UUD NRI 1945 is an original formulation that does not get changed. In UUD NRI 1945 after amendment, the provisions unlike referred in Article 27 section (1) as well as consist in Article 28D section (1) UUD NRI 1945, "Everyone has the right to ... equal treatment facing the law" and section (3) every citizen deserves equal opportunity in government ". The difference is in Article 28D section (1) the normality subject is every person, whereas in Article 27 section (1) the norm subject is every citizen.

${ }^{26}$ Satjipto Rahardjo, Law Science, (Bandung: Alumni, 2000), p. 19.

${ }^{27}$ Satjipto Rahardjo, Study ..., Ibid. p. 18-19. See also W. Fiedmann, Theory \& Philosophy of Law: Philosophical Idealism \& Justice Problems (Vol. II), translated by Mohamad Arifin's in original title: Legal Theory, (Publisher CV. Rajawali, Jakarta, 1990), p. 43. 
judge and no longer from the rule of law. Thus, when the legal certainty is ignored for justice, it can bear the so-called "the highest justice is the highest injustice" (summa justitia summa iniuria). ${ }^{28}$

The tension is forwarded by Franz Magnis Suseno included the nature of the law itself and would reappear in the conflict between the Theory of Natural Law and the Law Positivism. However, the tension does not need to thwart the law ideas. The law must be fair. A certainty is a legal basis. Without certainty, the justice can not be done. However, its certainly should not be absolute. In order to keep the law fair, there needs to be flexibility. ${ }^{29}$ In essence, when it only pays attention to legal certainty itself, then other elements are ignored. Conversely, if it only pays attention to the benefits, then the law certainty and justice is neglected, and if it pays attention to justice, then the legal certainty and expediency are neglected (Suroto \& MacAndrews, 1978).

d) The Justice and Its Meaning for Recognition of Customary Law Unity with Regional Regulations

Franz Magnis Suseno distinguishes a justice into two meanings, i.e. a justice in the formal and a justice in material meanings: Regarding the equality principle, Roberto Mangabeira Unger stated it is an element of material or substantive justice. No matter how substantive justice is defined, Roberto Mangabeira Unger, substantive justice is only achieved by treating different situations in different ways. ${ }^{30}$ The concrete situation is defined for each case is each case peculiarity must be considered and it can be implemented if the law is gracefully formulated. In terms of law formation, a fair law is a formulated law that allows for legislation enforcement under its laws, unlike a Regional Regulation, can accommodate any problem specificity. It is related to the recognition of regulation and customary law respect society units, the law is formulated on the direction of its recognition and respect policy, while the more concrete matter, i.e. the establishment of a certain customary law society unit and their trademark rights, is the material local regulatory content charge (Cindawati, 2011).

The justice understanding can also be observed from Moh. Mahfud MD views, justice has a dynamic nature that sometimes can not be accommodated in positive law. However, justice concept is consist of the rights protection meaning, equality, and position under the law and the proportionality principle between individual and social interests. The justice dynamic nature depends on the social atmosphere dynamics influenced by values and other norms in society, which can sometimes not be included in the positive law, Moh. Mahfud MD argued to be accommodated in positive law, the formula must be flexible, and therefore, the concrete thing feeling fair can be accommodated in the law implementation. Thus, this is about justice, which Franz Magnis Suseno calls justice in a material sense.

The equality principle injustice is as well as evident by John Rawls's theory of justice. He formulates 2 (two) principles of justice, i.e. (1) everyone should have equal rights over the broadest basic freedom, equal freedom for all and (2) social and economic inequality should be regulated in such a way, therefore (a) it is expected benefit for everyone; and (b) all positions and positions are open to all. ${ }^{31}$ Inequality, in the second principle of justice, is permissible when it benefits for everyone. Therefore, inequality should not be understood as an injustice. It is as well as noted by Roberto Mangabeira Unger, existing inequality needs to be offset by the inverse preferences provided by the law to the disadvantaged group.

Magnis-Suseno (1988), moving on to above justice understanding, which is theoretically distinguished into formal and substantive justice, then the principles consist of the sense of justice and its relationship with provisions in UUD NRI 1945. It should be noted that the right to special treatment in a specific (unequal) situation, unlike appears in the above table UUD NRI 1945 is set out in Article $28 \mathrm{H}$ section (2), "Everyone has the right to enjoy the convenience and special treatment for opportunity and the same benefits to achieve equality and justice "and in UU 12/2011, i.e. the provision of the law sole principle, that the Laws Content and Regulations must pay attention to population diversity, religion, ethnicity and class,

${ }^{28}$ Franz Magnis Suseno, Political Ethics ..., Op. Cit., p. 83.

${ }^{29}$ Ibid. p. 83-84. The Theory of Natural Law views the law mastering to conform to the moral norms of justice outside the positive law, whereas Positive Law Theory (Legal Positivism) argued that a law is fair due to it is legally enacted: the law defines what is just, in Ibid. 85 .

${ }^{30}$ Roberto Mangabeira Unger, Law in Modern Society toward a Criticism of Social Theory, (The Free Press-Collier Macmillan Publishers, New York-London, 19760), p. 198, "No matter how substantive justice is defined, it can be achieved by treating different situations differently."

${ }^{31}$ John Rawls, Theory of Justice: The Basics of Political Philosophy to Achieve Social Welfare in the State, translation, (Pustaka Pelajar, Yogyakarta, 2006), p.72. John Rawls, A Theory of Justice, (The Belknap Press of Harvard University Press, Cambridge-Massachusetts, 1971), p. 60.

Atmaja, G. M. W. (2018). Legal pluralism politics towards recognition of social unity in customary law and local regulation. International Journal of Social Sciences and Humanities, 2(2), 124-140. https://doi.org/10.29332/ijssh.v2n2.152 
special region conditions, which concerns sensitive issues in the social life, nation, and state (Article 6 section (1) letter $f$ UU 12/2011 and Explanation). In addition, it is also regulated in UU HAM (Human Rights Law), in order to uphold human rights, the differences and needs costmary law society should be concerned and protected by the law, society, and Government (Article 6 section (1) UU HAM).

Theoretically and normatively, there is an inequality recognition, due to the diversity of the population, religion, ethnic groups, and classes, special conditions of a region, and culture, and the differences and needs within the customary law society. The existence, unlike inequality, requires special treatment, ranging from the treatment in the arrangement field. There should be a special arrangement regarding the inequality. Related with customary law society units, which in UUD NRI 1945, it requires the state to recognize and respect it. unlike recognition and respecting are governed by law. However, given the differences and needs in customary law society units, as recognition and respect can not be done centrally in a law. It is, therefore, necessary to construct, that the law regulates the policy direction of recognizing and respecting the customary law unity, while their concrete recognition and respect is in the form of an affirmation for one or more customary law society units with the rules area (Sholahuddin \& Sadhana, 2018).

\subsection{Local Regulation on Recognition of Customary Law Unity}

In order to describe local regulations on the recognition of customary law unity gain a character and recognition pattern. Initial observations indicate the presence, there are 2 (two) local regulatory characters, i.e. (1) regional law regulation, which consists of the abstract - general law norms; and (2) regional regulations of determining character, including legal norms approaching individual concrete such as equity participation.

a) Bali Provincial Regulation on Desa Pakraman

Bali Province Regulation No. 3 / 2001 concerning Desa Pakraman (Bali Provincial Gazette in 2001 No. 29 Seri D No. 29) as amended by Bali Province Regulation No. 3 / 2003 on Amendment to Bali Province Regulation No. 3 / 2001 regarding Desa Pakraman (Bali Provincial Gazette in 2001 No. 11 / 2003, Bali Provincial Additional Gazette Regional No. 3).

\section{1) Background}

The Bali Provincial Regulation No. 3 / 2001 concerning Desa Pakraman (Bali Perda No. 3/2001) was established enactment at the time of Law No. 22 / 1999 regarding Regional Government, it is a legal basis for its establishment. The enactment of Regional Regulation resulted in Regional Regulation No. 06/1986 on the Status, Functions, and Roles of Indigenous Villages as a unit of customary law society in Bali Province (Bali Perda No. 06/1986) is no longer valid. The declaration is established under Law No. 5 / 1974 on Regional Government and Law No. 5 / 1979, is included in Article 19 section (1) Bali Province Regulation No. 3 / 2001.

There are reasons it is no longer valid No. 06/1986, can be known in consideration "Considering" letter $c$, Bali Perda No. 3/2001, i.e.:

That, Regional Regulation No. 06/1986 on the Status, Functions, and Roles of Indigenous Villages as the Unity of customary law societies in the Provinces of Bali First Level Region is no longer appropriate to era development, so it is deemed necessary to be replaced.

As well mentioned in General Explanation of Bali Perda No. 3/2001, numeric 1, included:

Regional Regulation No. 06/1986 on Position, Function, and Role of Indigenous Villages as a Unity of customary law in Bali Province level I have a very meaningful meaning due to the area rules have provided a foundation, formal jurisdiction on the existence of customary law in Bali, however, the society development and in occurrence with social change. Therefore, it quickly and withdrawal Law No. 5 / 1974 on the Principles of Local Governance in Law No. 5 / 1979 on Village Governance, is considered, It is necessary to amend the Regional Regulations No. 06 / 1986 in accordance with the development and change a social event in Bali. 
Thus, there are 2 (two) reasons for replacement No. 06/1986 with Bali Perda No. 3/2001, i.e.:

1. Bali Perda No. 06/1986 is no longer relevant for developing on the era therefore, it is necessary to be replaced.

2. Revocation of Law No. 5 / 1974 on Principles of Regional Governance and Law No. 5 / 1979 concerning Village Governance.

In 2003, Bali Provincial Regulation No. 3 / 2001 was amended by Bali Province Regulation No. 3 / 2003 (Bali Perda No. 3/2003). ${ }^{32}$ As a reason can be known in Consideration "Considering" letter $a$ Bali Perda No. $3 / 2003$, i.e.:

That, the provisions of Article 1 section 3, Bali Province Regional Regulation No. 3 / 2001 concerning Desa Pakraman need to be improved and the provisions of Article 9 section (6) Regional Regulation can not be implemented properly so that changes need to be made;

As well presented in General Explanation of Bali Perda No. 3/2003, that can be detailed as follows:

1. Sub-district Definition in Article 1 No. 3, Bali Perda No 3/2001 is adjusted in Law No. 22 / 1999 regarding Regional Government.

2. The provisions of Article 9 section (6) Perda Bali No 3/2001 can not be implemented properly due to matters relating to land and building tax shall be nationally regulated pursuant to Law No. 12 / 1985 concerning Land and Building Tax, has been Amended by Law No. 12 / 1994, therefore, it is necessary to be omitted by Amendment Regional Regulation.

The amendment substance consists in Article 1, Bali Perda No 3/2003, which included the following provisions:

In order to amend some provisions in Bali Provincial Regulation No. 3 / 2001 concerning Desa Pakraman has been enacted in Bali Provincial Gazette in 2001 No. 29 D Series No. 29 as follows:

1. The provisions of Article 1 section 3 is amended, therefore, it becomes entirely establish as follows: Sub-District is the working area for Sub-District Head as a Regency and City Area apparatus. ${ }^{33}$

2. The provisions of Article 9 section (6) are omitted. ${ }^{34}$

2) The Name of Regional Regulation

The title ${ }^{35}$ of regional regulation in the present study is Bali Province Regional Regulation No. 3/2001 on Desa Pakraman. The Regional Regulation changing it is entitled Bali Province Regional Regulation No. 3 / 2003 on Amendment to Bali Provincial Regulation No. 3 / 2001 regarding Desa Pakraman. The name of Regional Regulation shown in the title of Regional Regulation itself is Regional Regulation on Desa Pakraman. This name is as well as listed in the Dictum section, ${ }^{36}$ after the lexicon Define, i.e. PERATURAN DAERAH PROPINSI BALI TENTANG DESA PAKRAMAN (Bali Provincial Regulation regarding Desa Pakraman). ${ }^{37}$

In order to compare Bali Perda No. 06/1986, there is a renaming of Regional Regulation, from Local Regulation on Desa Adat to Regional Regulation on Desa Pakraman. In Bali Perda No. 06/1986, after the phrase of Desa Adat accompanied by the phrase of the Unity of customary law society, whereas in Bali

${ }^{32}$ Hereinafter called Perda Desa Pakraman refers to Bali Regulation 3/2001 as amended by by Bali Law 3/2003.

${ }^{33}$ Previously, Article 1 point 3 stated: "Sub-District is working area of subdistrict head as a district administration apparatus."

${ }^{34}$ Previously, Article 9 section (6) stated: "Desa Pakraman land and the land belonging to Desa Pakraman is free of tax."

${ }^{35}$ The Title of Legislation consist of information about the type, number, year of enactment or stipulation, and name of Legislation. Number 2 Technique of Laws and Regulations Preparation (Appendix II, vide Article 64 section (2) Law 12/2011).

${ }^{36}$ Dictum included lexicon: a. decided; B. established; and c. type and name of Legislation. Number 55 Technique of Laws and Regulations Formulation, (Appendix II, vide Article 64 section (2) Law 12/2011).

${ }^{37}$ In accordance with number 59 Technique of Laws and Regulations Formulation (Appendix II, vide Article 64 section (2) UU 12/2011), the name of Regional Regulation in Dictum without the phrase of Bali Province. See also the Technique of Legislation Formulation, number 37 (vide Article 1 of Presidential Decree No. 44 / 1999 concerning Technique of Preparation of Legislation and Draft Law Form, Draft of Government Regulation, and Draft of Presidential Decree). This Presidential Decree is still valid currently Regional Regulation is made and in 2004 the new one is declared invalid through Article 57 letter $c$, Law No. $10 / 2004$.

Atmaja, G. M. W. (2018). Legal pluralism politics towards recognition of social unity in customary law and local regulation. International Journal of Social Sciences and Humanities, 2(2), 124-140. https://doi.org/10.29332/ijssh.v2n2.152 
Perda No. 3/2001, behind the phrase of Desa Pakraman is not followed by the phrase of the Unity of customary law society.

The replacement of the term "Desa Adat" into "Desa Pakraman", according to the General Elucidation, No. 3, Bali Perda No. 3/2001, viewing the term "pakraman" has been used since the village in Bali. ${ }^{38}$ Although, the terms used are different, however, have the same meaning and together as a unity of customary law can be observed in Article 1 letter $e$, Bali Perda No. 06/1986 and Article 1 No. 4, Bali Perda No. 3/2001, as outlined in the following matrix:

Table 1

The Definition of Desa Adat and Desa Pakraman

\begin{tabular}{|c|c|}
\hline $\begin{array}{l}\text { Desa Adat } \\
\text { [Article } 1 \text { letter } e \text {, Bali Perda No. } \\
\text { 06/1986] }\end{array}$ & $\begin{array}{l}\text { Desa Pakraman } \\
\text { [Article } 1 \text { No. 4, Bali Perda No. 3/2001] }\end{array}$ \\
\hline $\begin{array}{l}\text { Unlike Desa Dresta is a unitary of } \\
\text { customary law society in Bali Province } \\
\text { Level I }\end{array}$ & The unity of customary law society in Bali Province \\
\hline $\begin{array}{l}\text { Those who have a unity of tradition and } \\
\text { manners of social interaction in Hindu } \\
\text { society from generation to generation in } \\
\text { Kahyangan Tiga (Kahyangan Desa/main } \\
\text { temple in the village) }\end{array}$ & $\begin{array}{l}\text { Those who have a unity of traditions and } \\
\text { manners of social interaction of Hindu society } \\
\text { from generation to generation related in } \\
\text { kahyangan Tiga or kahyangan desa. }\end{array}$ \\
\hline $\begin{array}{l}\text { Those who have a particular area and its } \\
\text { own property and is right to manage their } \\
\text { own household. }\end{array}$ & $\begin{array}{l}\text { Those who have a particular area and its own property } \\
\text { and is right to manage their own household. }\end{array}$ \\
\hline
\end{tabular}

Source: Processed from Article 1 letter $e$, Regional Regulation No. 06 / 1986 and Article 1 No. 4, Bali Provincial Regulation No. 3 / 2001

\section{3) Regulated Subject Matter}

The subject matter that is set regarding Desa Pakraman is formulated in Chapter II to Chapter X, Desa Pakraman Law, as can be expressed in the following table.

Table 2

Basic Material Regulated in Bali Province Regional Regulation No. 3/2001 as amended by Bali Province Regional Regulation No. 3/2003

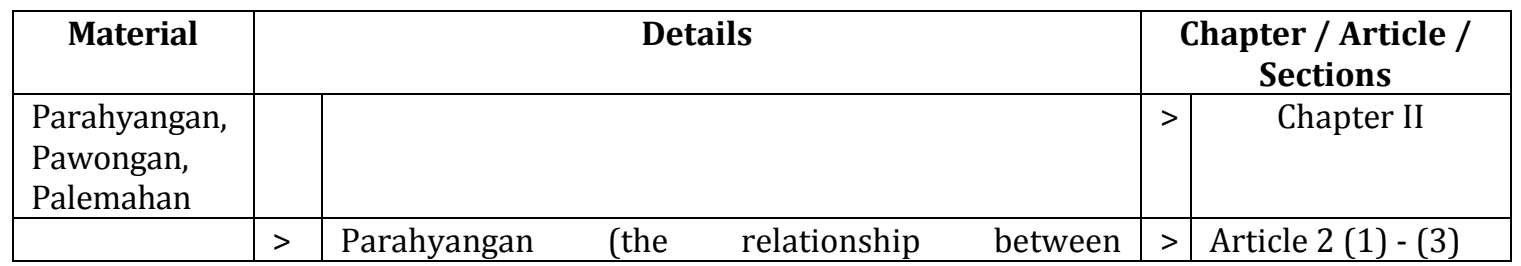

${ }^{38}$ Carol Warner describes the choice of Desa Pakraman term, instead of Desa Adat (customary village), replacing the Arabic (adat) label with original Indian language (krama), a shift consciously seeking an identity for the rule drafters. Focusing on krama is considered appropriate for democratic reform era due to it emphasizes on the basis of collective institutions (krama) for local authorities. Krama refers to the customs practice, rules, and laws (etiquette), and determines local governance by deliberation of decision making (village manners, krama banjar). Carol Warner, "Adat in Balinese practice and discourse: Positioning commonweal principles, in Jamie S. Davidson, David Henley, Sandra Moniaga, eds., Adat in Indonesian Politics, translated by Emilius Ola Kleden and Nina Dwisasanti from the original title; The revival of tradition in Indonesian politics: the development of adat from colonialism to indigenism, (Jakarta: Yayasan Pustaka Obor Indonesia and KITLV-Jakarta, 2010), p. 189-190. 


\begin{tabular}{|c|c|c|c|c|}
\hline & & $\begin{array}{l}\text { krama/human and God), the responsibility of } \\
\text { kahyangan desa, dang kahyangan and sad } \\
\text { kahyangan that is in desa pakraman/banjar } \\
\text { pakraman area. }\end{array}$ & & \\
\hline & $>$ & $\begin{array}{l}\text { Pawongan (the relationship among krama/human), } \\
\text { classification of villagers and their rights and } \\
\text { obligations }\end{array}$ & $>$ & Article 3 (1) - (8) \\
\hline & $>$ & $\begin{array}{l}\text { Palemahan (the relationship among krama/human } \\
\text { with environment of desa pakraman/banjar } \\
\text { pakraman), desa pakraman area and its change. }\end{array}$ & $>$ & Article 4 (1) - (3) \\
\hline $\begin{array}{l}\text { Duties and } \\
\text { Desa } \\
\text { Pakraman } \\
\text { Authority }\end{array}$ & & & $>$ & Chapter III \\
\hline & $>$ & The duty of Desa Pakraman & $>$ & Article 5 \\
\hline & $>$ & Desa Pakraman Authority & $>$ & Article 6 \\
\hline $\begin{array}{l}\text { Desa } \\
\text { Pakraman } \\
\text { Prajuru/Staff }\end{array}$ & & & $>$ & Bab IV \\
\hline & $>$ & Desa Pakraman staff and how to fill it & $>$ & Article 7 \\
\hline & $>$ & The duties of Prajuru Desa Pakraman & $>$ & Article 8 \\
\hline $\begin{array}{l}\text { Desa } \\
\text { Pakraman } \\
\text { Property }\end{array}$ & & & $>$ & Chapter V \\
\hline & $>$ & The properties type of Desa Pakraman & $>$ & Article $9(1)$ \\
\hline & $>$ & $\begin{array}{llll}\text { Management, transfer/status change of Desa } \\
\text { Pakraman properties }\end{array}$ & $>$ & Article 9 (2) \& (3) \\
\hline & $>$ & Supervision of Desa Pakraman property & $>$ & Article 9 (4) \\
\hline & $>$ & $\begin{array}{l}\text { The village land in Desa Pakraman and/or the land } \\
\text { belonging to Desa Pakraman can not be certified on } \\
\text { behalf of the person. }\end{array}$ & $>$ & Article $9(5)$ \\
\hline $\begin{array}{l}\text { Desa } \\
\text { Pakraman } \\
\text { Incomes }\end{array}$ & & & $>$ & Chapter VI \\
\hline & $>$ & Revenue source of Desa Pakraman & $>$ & Article $10(1)$ \\
\hline & $>$ & The income use of Desa Pakraman & $>$ & Article $10(2)$ \\
\hline & $>$ & Governance and use of Desa Pakraman income & $>$ & Article $10(3)$ \\
\hline $\begin{array}{l}\text { Desa } \\
\text { Pakraman } \\
\text { Awig- } \\
\text { Awig/rules }\end{array}$ & & & $>$ & Chapter VII \\
\hline & $>$ & The letter of Desa Pakraman rules & $>$ & $\begin{array}{l}\text { Article } 11(1) \& \\
(2)\end{array}$ \\
\hline & $>$ & Confirmation and noted of Desa Pakraman rules & $>$ & $\begin{array}{l}\text { Article } 12 \text { (1) \& } \\
(2)\end{array}$ \\
\hline $\begin{array}{l}\text { Empowerme } \\
\text { nt and } \\
\text { Preservation } \\
\text { for Desa }\end{array}$ & & & $>$ & Chapter VIII \\
\hline
\end{tabular}

Atmaja, G. M. W. (2018). Legal pluralism politics towards recognition of social unity in customary law and local regulation. International Journal of Social Sciences and Humanities, 2(2), 124-140. https://doi.org/10.29332/ijssh.v2n2.152 


\begin{tabular}{|l|l|l|l|l|}
\hline Pakraman & & \multicolumn{1}{|l|}{} & \\
\hline & $>$ & $\begin{array}{l}\text { The direction of empowerment and preservation of } \\
\text { Desa Pakraman rules }\end{array}$ & $>$ & Article 13 (1) \\
\hline & $>$ & $\begin{array}{l}\text { The purpose of empowerment and preservation of } \\
\text { Desa Pakraman }\end{array}$ & $>$ & Article 13 (2) \\
\hline $\begin{array}{l}\text { Pakraman } \\
\text { Council }\end{array}$ & & & $>$ & Chapter IX \\
\hline & $>$ & The main council, middle council, and village council & $>$ & Article 14 \\
\hline & $>$ & Establishment of village council & $>$ & Article 15 (1) \\
\hline & $>$ & Establishment of middle council & $>$ & Article 15 (2) \\
\hline & $>$ & Charging board of main, middle, and village councils & $>$ & Article 15 (4) \\
\hline & $>$ & $\begin{array}{l}\text { Participants of paruman agung/high meeting, } \\
\text { paruman/mid meeting, and paruman alit/small } \\
\text { meeting }\end{array}$ & $>$ & Article 15 (5) \\
\hline $\begin{array}{l}\text { Pacalang/Bal } \\
\text { inese } \\
\text { Security }\end{array}$ & $>$ & $\begin{array}{l}\text { Temporary leaders of paruman agung, paruman } \\
\text { madya, dan paruman alit }\end{array}$ & $>$ & Article 15 (6) \\
\hline & $>$ & Appointment and dismissal of Pacalang & Chapter X \\
\hline & & Article 17 (3) \\
\hline
\end{tabular}

Source: Processed from Bali Province Regional Regulation No. 3 / 2001 as amended by Bali Province Regional Regulation No. 3 / 2003

Observing regulated subject matter indicates that Bali Provincial Regulation No. 3 / 2001 as amended by Bali Provincial Regulation No. 3 / 2003 does not consist of recognition or confirmation for Desa Pakraman as a unit of customary law society, however, includes an element that must be submitted in the unity of the society is called Desa Pakraman i.e. existence of kahyangan tiga as parahyangan element, in addition to the elements commonly found in a unity of customary law society, namely the existence of customary law society and customary government (krama desa/villagers and prajuru desa and pecalang as element of pawongan), customary law area (desa pakraman area as element of palemahan), customary law instruments (awig-awig desa pakraman), and customary property (desa pakraman property).

In addition, the newly introduced institution called Desa Pakraman council that has the main duty to protect the customs and the main authority to discuss the issues regarding adat and religion for the benefit in Desa Pakraman. In the context of Desa Pakraman as a unit of the customary law, society can utilize its rights guaranteed both constitutionally and legally, it is necessary to consider the existence of Regional Regulation that confirmed the existence of Desa Pakraman. If Desa Pakraman concerned is located in one regency/city, then the enactment of local regency/city regulation. If Desa Pakraman is located in more than 2 (two) or more districts/cities, then the enactment to Bali Provincial Regulation.

\section{Conclusion}

Legal political pluralism i.e. an exist a plurality of customary law society units that require special recognition with local regulations. The state of law basis defines as a law of government instrument must ensure justice, benefit, and legal certainty. A justice requires the law is able to accommodate the special conditions or peculiarities of every case, therefore, the law must be flexible, and the concrete accommodation of special conditions is done by local regulations. The customary law unity has a specificity that requires flexible regulation in the law, and enforcement to its acknowledgment with local regulations. The utilization wonder, the law can make people happy by ensuring access to their rights. The recognition of customary law unity society guarantees access to rights, in accordance with laws that mandate acknowledgment with local regulations. The legal certainty requires that the law can be formulated, unlike a clear and systematic way. It 
can be made thus, it is clear about the recognized identity is given for more limited scope and local government to be better recognize local uniqueness.

Conflict of interest statement and funding sources

The author declared that he has no competing interest. The study was financed by personal funding.

Statement of authorship

The author has a responsibility for the conception and design of the study. The author has approved the final article.

Acknowledgments

The author would like to thank the editor of IJSSH for their support, valuable time and advice.

Atmaja, G. M. W. (2018). Legal pluralism politics towards recognition of social unity in customary law and local regulation. International Journal of Social Sciences and Humanities, 2(2), 124-140. https://doi.org/10.29332/ijssh.v2n2.152 


\section{References}

1. Bedner, A. (2010). An elementary approach to the rule of law. Hague Journal on the Rule of Law, 2(1), 4874.

View in (Google Scholar)

2. Black, H. C., Garner, B. A., \& McDaniel, B. R. (1999). Black's law dictionary (Vol. 196). St. Paul, MN: West Group.

View in (Google Scholar)

3. Bourchier, D., \& Hadiz, V. (Eds.). (2014). Indonesian politics and society: A reader. Routledge. View in (Google Scholar)

4. Cindawati. (2011). The Principle of Balance in International Business Contract Law (in Anticipation of the Free Trade Era). Indonesian J. Int'l L., 9, 491.

View in (Google Scholar)

5. Dicey, A. V., \& Wade, E. C. S. Introduction to the Study of the Law of the Constitution (Vol. 10). London: Macmillan.

View in (Google Scholar)

6. Lask, E., Radbruch, G., Dabin, J., \& Wilk, K. (1950). The legal philosophies of Lask, Radbruch, and Dabin. View in (Google Scholar)

7. Leyh, G. (2011). Pendidikan Hukum dan Kehidupan Publik. View in (Google Scholar)

8. Li, T. M. (1999). Compromising power: Development, culture, and rule in Indonesia. Cultural anthropology, 14(3), 295-322.

View in (Google Scholar)

9. Magnis-Suseno, F. (1988). Etika politik: prinsip-prinsip moral dasar kenegaraan modern. Gramedia Pustaka Utama.

View in (Google Scholar)

10. Manan, B. (1990). Relationship Between Central and Regional According to the principle of decentralization by 1945.

View in (Google Scholar)

11. Nahak, S. (2017). Criminal Law Policy on Land Functions Impacting Climate Change in Indonesian National Law Perspective. International Journal of Social Sciences and Humanities (IJSSH), 1(3), 28-39.

View in (Google Scholar)

12. Rahman, H. A. (2011). Public involvement on environmental issues in Malaysia with reference to Alor Star, Kedah. In 2011 International Conference on Environmental, Biomedical and Biotechnology IPCBEE, Singapore (Vol. 16).

View in (Google Scholar)

13. Saptomo, A. (2010). Hukum dan kearifan lokal: revitalisasi hukum adat Nusantara. Grasindo. View in (Google Scholar)

14. Sholahuddin, A., \& Sadhana, K. (2018). Policy implementation of nazhir endowments. International Research Journal of Engineering, IT and Scientific Research (IRJEIS), 4(2), 63-72.

View in (Google Scholar) 
15. Suarta, I. M. (2017). Revitalization of Oral Literature Tradition of Balinese Society Based Character Values As Deradicalism Effort. International Journal of Social Sciences and Humanities (IJSSH), 1(3), 8-16.

View in (Google Scholar)

16. Suroto, S., \& MacAndrews, C. (1978). Bibliografi beranotasi perihal tanah di Indonesia: oleh Soeri Soeroto [dan] Colin MacAndrews. Lembaga Studi Pedesaan dan Kawasan, Universitas Gadjah Mada.

View in (Google Scholar)

17.Vujčić, V. (2006). Bhikhu Parekh: Rethinking Multiculturalism. Cultural Diversity and Political Theory. Politička misao: časopis za politologiju, 42(4), 133-137.

View in (Google Scholar)

Atmaja, G. M. W. (2018). Legal pluralism politics towards recognition of social unity in customary law and local regulation. International Journal of Social Sciences and Humanities, 2(2), 124-140. https://doi.org/10.29332/ijssh.v2n2.152 


\section{Biography of Author}

\begin{tabular}{|l|l|}
\hline \hline & $\begin{array}{l}\text { Gede Marhaendra Wija Atmaja is a senior lecturer. He works in Udayana } \\
\text { University, Jln. PB Sudirman, Bali, Indonesia. He is interested in the area of the } \\
\text { study included law and politics. } \\
\text { Email: haen.wia@gmail.com }\end{array}$ \\
\hline
\end{tabular}

